\title{
Regenerative Food Systems to Restore Urban-Rural Relationships: Insights from the Concepción Metropolitan Area Foodshed (Chile)
}

\author{
Ana Zazo-Moratalla ${ }^{1, * \mathbb{C}}$, Isidora Troncoso-González ${ }^{1}\left(\mathbb{D}\right.$ and Andrés Moreira-Muñoz ${ }^{2}$ (]) \\ 1 Department of Planning and Urban Design, Universidad del Bio-Bio, Av. Collao 1202, Concepción 4030000, \\ Chile; itroncoso@icloud.com \\ 2 Instituto de Geografía, Pontificia Universidad Católica de Valparaíso, Av. Brasil 2241, Valparaíso 2340000, \\ Chile; andres.moreira@pucv.cl \\ * Correspondence: azazo@ubiobio.cl
}

Received: 29 December 2018; Accepted: 6 April 2019; Published: 21 May 2019

\begin{abstract}
Cities, in recent years, have seen their functional and metabolic relationships with their agrarian hinterland being either broken off completely or substantially damaged. Within this context, Local Food Systems (LFS) can play a key role in restoring the supply relationships under regenerative assumptions. This paper analyses LFS within the Concepción Metropolitan Area (CMA) as a representative case of Metropolitan Areas in Chile. The aim of the paper is to evaluate whether LFS are regenerating sustainable rural-urban relationships, and to accomplish this goal, foodsheds have been used as a methodological tool to both characterise and represent food traceability. For this purpose, three quantitative foodshed indicators have been applied and three qualitative spatial analytical categories of the Regenerative Food Systems (RFS) defined to decode the behaviour of LFS in the CMA. The proposed method has been successful as an initial exploratory attempt to characterize the regenerative potential of RFS. The results highlight that LFS in the CMA are certainly restoring relationships between the city and its surrounding farmland by establishing new and renewed supply linkages. Further, the application of this method has shed light on some key aspects that show how an LFS is being converted into a potential RFS.
\end{abstract}

Keywords: Local Food Systems; diversity; flexibility; self-reliance; local scale

\section{Introduction}

Large and medium-sized cities are embedded in the global urban phenomenon of urbanization that has damaged, and even broken off, their functional and metabolic relationships with their surrounding environment [1]. Among them, food supply is the oldest [2] and primary urban-rural relationship [3-5] that has been most significantly affected [6].

Two main reasons have led to this breakdown in the city-countryside relationship, namely, urban growth and relocation of food production $[7,8]$. The attraction of people to cities as working poles has led to suburbanization $[9,10]$ and the expansion of urban sprawl [11-13], while the physical expansion of the city has resulted in a fragmented and disperse model that has spread across the land that originally fed the urban population $[14,15]$. Furthermore, from the second half of the 20th century onwards, the global food system has detached production from consumption in both space and time [16,17]. Relocation of food production has led city populations, who are no longer reliant on their regional farmland or dependent on the seasonality and singularity of local foodstuffs, to become the main consumers [18,19]. This has led to a homogenization of the citizen's diet [20], entrusting food security to agroindustrial businesses [21-23]. This breakdown has deeply affected the behaviour 
of urban metabolism, transforming the urban food system into a linear, long distance system that is dependent on swings and decisions of global markets. The main result is that cities currently suffer from an unavoidable food vulnerability [24].

Within this context, Local Food Systems (LFS) [25] have emerged against industrial and transnational food chains as different socioeconomic and geographic structures, relocalizing production, while building closer links to urban consumers. LFS involve people, institutions, resources, and logistics platforms, alongside intertwined relationships, to produce, distribute, and consume food [26]. The "local" of LFS is a malleable concept and does not mean a concrete scale [27-29]. It is defined by a triple proximity between producers and consumers: physical, social, and identitarian [25]. This multidimensional proximity allows consumers to identify the localness of the foodstuffs versus industrial food supplies $[30,31]$ while shaping the LFS as renewed urban-rural relationships [28]. These links between a food source and its urban destination may not be completely new, but what is key is that they are being restored, regenerating the damaged urban-rural relationship [32-34]. In middle-income countries like Chile, there are still historical and location-based food systems; although these have been severely affected by industrial agriculture $[35,36]$. The prevalence of these engrained LFS and increasingly relentless urbanization have prompted questions about the possibilities and potentialities of fostering more sustainable food systems [37]. This paper explores how LFS are able to build new urban-rural relationships or reformulate old ones under regenerative assumptions.

The regenerative approach seeks to move beyond the ambiguities of sustainable approaches [38]. While "sustainable" means that a system could be sustained over an extended period of time, "regenerative" goes beyond the mere idea of preservation and proposes enhancing a substantial interconnection between nature and society [39] in order to adapt to natural limits [40]. When food is the main axis of this restoration, people, spaces, and resources coalesce, forming a Regenerative Food System (RFS) with healthy, natural, and social systems that are both responsive and responsible [41,42]. Dalhberg [42] defined RFS as a system that regenerates the relationship between natural and social dimensions, one which is based on a food production, distribution, and consumption, and is aware of its environmental effects. An RFS should consider different dimensions, it should integrate issues like social justice, intergenerational equity, and interspecies balance [41], and it should work at multiple levels (household, neighbourhood, city, metropolis, and regional) and be conceived with the idea of building healthier cities and territories. An RFS is a system that aims to reach a degree of self-reliance, where the system is able to provide for itself, as much as possible, before joining higher-level systems to provide for unmet needs [43]. This conceptual framework is recovering and reformulating the RFS concept, seeking to analyse whether LFS can enhance urban-rural supply relationships in a given context.

Foodsheds provide the methodological framework to analyse RFS. Foodshed as a term, was coined by Hedden in 1929 as the barrier which guides the flow of foodstuffs [44]. In 1991, Getz [45] adapted the concept to refer to the area defined by the food supply support structure and the mechanisms used to feed the urban population. Since then, the concept has been used to describe both the geographical idea of the foodshed as the perimeter of the food region of a given city $[46,47]$ and to define the traceability of alternative food systems that connect producers and consumers [25,48,49]. As a methodological tool, foodshed has been implemented to analyse potential urban self-sufficiency [50-59] and to apply a spatial analysis of the food flow to evaluate urban-rural connections and the level of self-reliance [60-63]. This second methodological focus has mainly been applied at an urban food system scale or at a specific LFS level. However, this paper proposes to break down the urban local food system into those LFS that operate differently, to build each foodshed separately and analyse whether they behave as RFS. Finally, analysis of the complementarity among LFS will determine whether they are increasing the self-reliance of the system and regenerating urban-rural links.

In summary, this paper aims to design and apply a foodshed method to analyse whether LFS in a Chilean Metropolitan Area have regenerative potential to restore or build new sustainable rural-urban 
relationships. The application of this method intends to conclude by determining some key aspects that convert an LFS into a potential RFS.

\section{Description of the Case}

\subsection{Domestic Context}

Over the last thirty years, Chilean cities have seen an increasing urban sprawl as part of the domestic urbanization phenomena, leading to an important loss of farmland and other semi-natural areas around the largest populated centers [64-66].

Moreover, since the late 1970s, Chile has developed a policy that has sought to position the country as an international agri-food stakeholder, encouraging access for the main transnational actors within the domestic agroindustry [67]. The result is that large-scale agroindustry is currently concentrated in the central valley, playing an important role in the country's economic matrix, with foodstuffs comprising more than a quarter of all Chilean exports [68]. The economic weight of this agroindustry has two implications. First, the Chilean urban food system has become very industrialized and dependent on these agro-industrial systems. These can supply a wide range of fruit and vegetables all-year-round, overcoming natural and distance limitations [69]. In response, different social movements have begun to wonder where food is being produced, who is involved, and how this is being done. The second implication is that, in a context where social and environmental consequences of these neoliberal and agro-industrial systems are now visible [70], the importance of small and medium agriculture is increasing. This agricultural system is mainly linked to peasant culture and to indigenous populations whose practices have become a means of resistance to the global food system [36,37].

The case in question is located in the Biobio Region. Thanks to its geography, set between the Atlantic coastline and the Andes mountains with a smaller coastal range rising up in between, the Biobio Region has a Mediterranean climate with an oceanic influence [71]. The region's temperature oscillation between peak season (summer) and lean season (winter), alongside the fact its rainfall is concentrated in winter, have important implications for regional agriculture and its production methods.

Furthermore, the Biobío Region has seen an intensive land use change over the last twenty years, with $25 \%$ of the farmland being lost as the forestry industry encroached [72]. On the other hand, it is a peculiar area, as it continues to have many farm-based small operations, and a consolidated peasant movement $[73,74]$, providing the primary elements for a transition towards a regenerative food system $[26,33]$.

The analysis was made for the Concepción Metropolitan Area (CMA), which is the second-largest conurbation in Chile with a population of almost one million. It is located $500 \mathrm{~km}$ south of Santiago on the coast and comprises eleven townships in total (Figure 1). Concepción is the main hub, both spatially and functionally. It is set in the center of the CMA and is surrounded by the rest of townships, which are spatially spread within two concentric rings. It is also the main service center and the rest of townships have a relationship based on functional dependency. The coastal townships are old industrial settlements that are currently being used as dormitory towns, while those located to the north have kept up their rural traditions. On the fluvial cost, the closest townships are also used as dormitory towns, while the ones further afield remain less integrated into the metropolitan dynamics, with rural activity persisting [75]. The CMA's urbanization process has seen it lose virtually all its farmland over the last fifty years, with most of the areas near to the central hub of the city being developed [76].

In terms of the conventional food system in the CMA, fruits and vegetables are commercialized through a few supermarket chains linked to domestic and global supply chains, and through a large network of street food markets spread throughout the CMA [77]. These networks are mainly linked to major logistic distribution wholesalers, which receive foodstuff from the domestic food supply chain. 


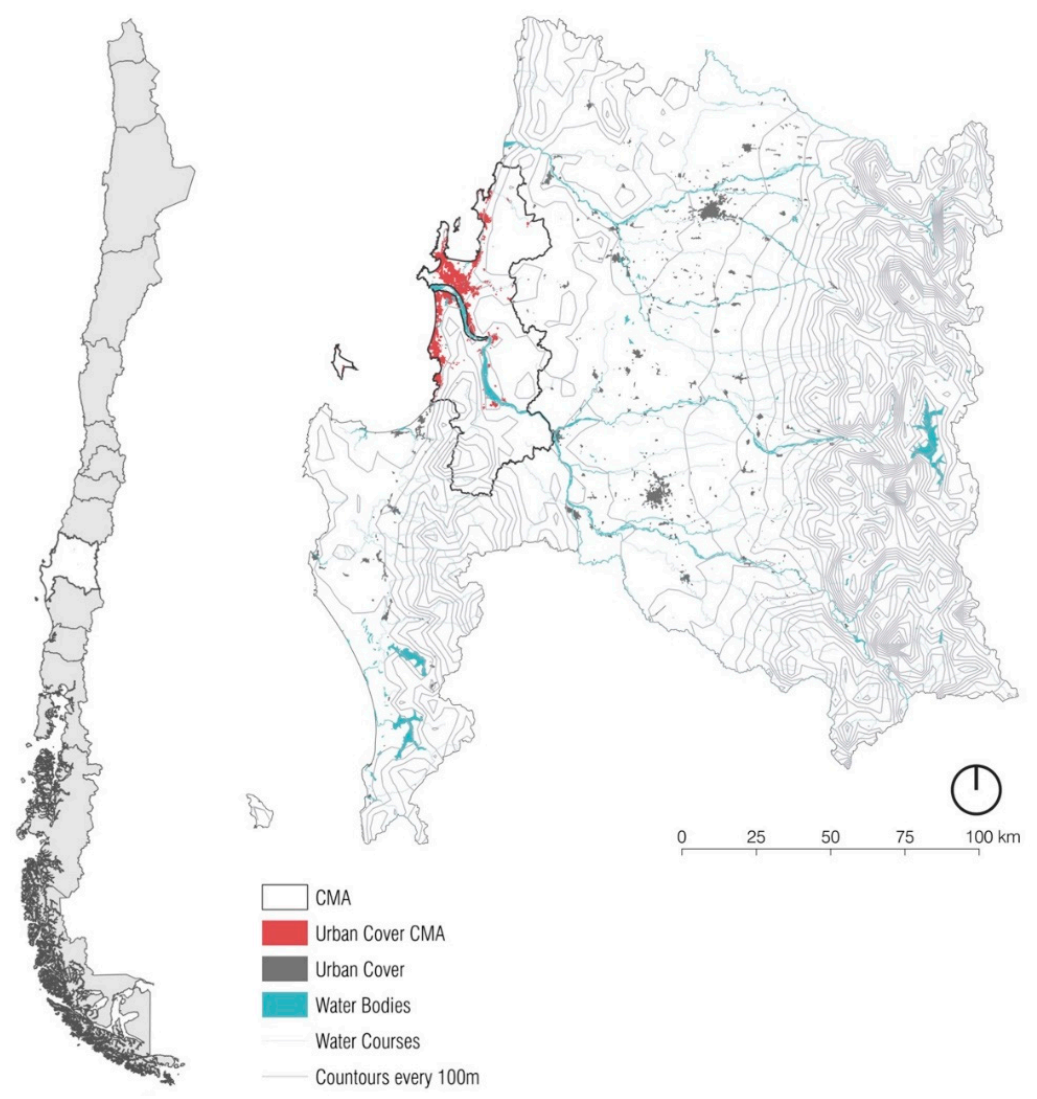

Figure 1. Location of the Case in Chile and in the Biobío Region. CMA, Concepción Metropolitan Area.

\subsection{Local Food Systems in the Concepción Metropolitan Area}

Concepción has become a hive of activity as the city has seen a transition towards new nourishment alternatives over recent years. New farmer and organic markets, organic and health food shops and local restaurants have sprung up throughout the Metropolitan Area in the last ten years. Before that, although periurban agriculture subsisted, the connection with the city was embedded in the conventional food system that had lost food traceability. These new nodes are the visible urban side of the LFS that connect the city's neighbourhoods with the countryside's supplier farmland, making their agroecology and food sovereignty practices visible by maintaining food traceability.

Previous research based on a qualitative approach identified two kinds of young LFS operating in Concepción: The Urban Local Food System (ULFS) and the Peasant Local Food System (PLFS) [33]. A preliminary identification of key actors and the subsequent in-depth interviews allowed an understanding of their internal dynamics. The main difference is the area where the driver agents act from, namely from urban to rural (ULFS) or from rural to urban (PLFS). The ULFS is driven by citizens building new trust-based connections with the countryside. Its urban expression mainly comprises fledgling urban food stores concentrated in downtown Concepción, which are supplied with foods that mainly come from local agroecological projects run by neo-rural operations and peasants spread throughout the regional area and at most have only been running for three years. The PLFS are driven by associations of local peasants engrained in specific farmland working on reformulating old food systems and conventional practices to reconnect with the city. Its urban expression side comprises farmer and organic markets, which have spread throughout the CMA over the last decade. Some of them started as street markets, but the value given to their peasant and agroecological practices is more recent. The scale and spatial distribution of the supplier foodshed of both LFS is currently unknown. The same can be said about the regenerative features of the rural-urban links of these LFS. 


\section{Materials and Methods}

\subsection{Methodological Framework}

The design of the foodshed methodology applies a quantitative and qualitative approach. Analysis of urban-rural relationships is meanwhile done, by analyzing traceability of fresh and processed food from the visible urban side where the accessibility to food for urban population takes place, to reach the food source and build the foodshed. However, characterizing the foodshed through quantitative indicators is a necessary measure to make a more in-depth analysis of the results. On the other hand, a qualitative method has to be defined to understand the results of the indicators under regenerative assumptions. As a result, the methodology is organized in three stages. The first identifies the sample selection, data collection and data processing. The second shapes the foodshed indicators and builds the foodshed maps for ULFS and PLFS in summer (peak production season) and winter (lean production season). While, the purpose of the third is to define the regenerative features of an RFS and to describe the relationship with the foodshed indicators. This process will lead to evaluating whether LFS in the CMA are indeed restoring urban-rural relationships under regenerative assumptions (Figure 2).

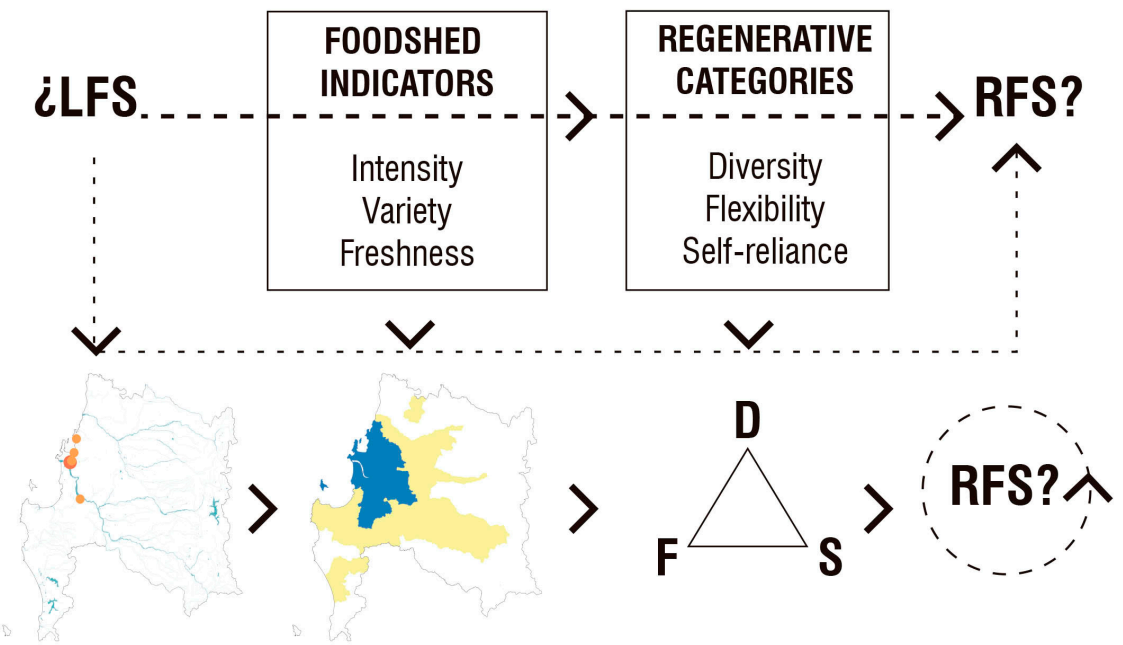

Figure 2. Conceptual Map of the Method. LFS, local food system; RFS, regenerative food system.

The sample selection was identified for the first stage. The purpose was to locate the visible urban side of ULFS and PLFS that are currently the destination of the foodshed's supply structure. For this purpose, it was determined that each point of sale was an urban point, and the spatial concentration of urban points with any kind of organization was an urban node. This is the case for street food markets where some ephemeral stands, located in public spaces, are organized under municipal regulations.

A snowball method was applied, and 41 urban points, corresponding to local food shops and restaurants, and 61 urban nodes, corresponding to all the street food markets within the CMA, were identified. The selection criteria set was the percentage of foodstuffs that reach both urban points and nodes as a destination of the LFS. Only 7 urban points had a percentage of local foodstuffs of up to $25 \%$, and all of these were related to ULFS. Meanwhile, 4 urban nodes were chosen because the percentage of local vegetables and fruit was nearly $100 \%$. These were all organized by proximity peasants promoting agroecological practices, so all belong to PLFS. The other 57 urban nodes had a few urban points with local foodstuffs, but these street markets were mainly comprised by retail traders embedded within the industrial food system. This selection was based on the information collected from field work.

After this, a standardized survey was applied to all the urban points: 7 surveys were made to the ULFS and 46 to the 4 urban nodes of the PLFS. Two basic sets of data were sought. First, the local foodstuff that each urban point was receiving as the destination of the foodshed's supply structure was collated, with a list of foodstuffs made for each one. Second, the origin of each foodstuff. A Municipal scale was considered appropriate to standardize answers related to the origin. This scale is understood 
as the administrative boundary where the supplier farmland is included. As a result, the supplier municipality was added to the list of foods.

The survey was applied in winter 2017 (June, July, and August) and summer 2017-2018 (December, January, and February). This double survey allowed tracking changes in the supply rural-urban relationships between peak and lean seasons. However, information regarding the volume of foodstuffs could not be collected because this data was not available.

The data collected was tabulated and processed separately for ULFS and PLFS. Then, the data was organized in matrices by spatial units; the supplier municipalities were the rows and the data about the foods were the columns. A classification of the foodstuffs into fresh and processed produce was also made and included.

\subsection{Determining the Foodshed Indicators}

The second stage comprised building the geographical foodshed for each of the LFS in the CMA and defining three indicators that show the inherent features of ULFS and PLFS as separate systems.

With the data processed, each matrix was joined to the vectoral layer of the municipalities of the Biobio Region in QGis 3.0. This software allowed representing the geographical foodshed of each system all-year round, shedding some light on each food print on the food scale.

Once this was done, three foodshed indicators were defined to characterize the foodshed beyond the food-print: (1) Intensity, (2) Variety, and (3) Freshness.

- Intensity: This indicator considers the strength of urban-rural relationships between the source of supply and the destination. Each supplier municipality shows in the foodshed indicator map, the degree of intensity of its relationship with the LFS' urban side: very low, low, medium, high, and very high. This indicator looks to reveal the intensity foodshed scale of each system. For practical purposes, intensity corresponds to the number of foodstuffs that each municipality supplies to ULFS and PLFS.

- Variety: This indicator considers the variety that the source of supply is providing to the LFS urban side. Each supplier municipality shows in the foodshed indicator map, the degree of variety its production has: very low, low, medium, high, and very high. This indicator considers the variety foodshed scale of each system. For practical purposes, variety is the number of vegetable and fruit varieties that each municipality supplies to ULFS and PLFS.

- Freshness: This indicator gives insight into the localness of fresh food that the source of supply is providing to the LFS' urban side. Each supplier municipality shows in the foodshed indicator map, the percentage of fresh food provided versus the total number of foodstuffs provided (intensity). This indicator looks to show the fresh foodshed scale of each system. For practical purposes, the freshness corresponds to the percentage of vegetables and fruits versus processed food that each municipality supplies to ULFS and PLFS.

The intensity indicator has been created as an alternative to the real volume indicator, as it was impossible to collect this information. The data collates the total number of foodstuffs found in the different points and nodes. However, this implies the reiteration of some products within a single node which may also come from the same or different districts. This provides an idea of the access of food that the LFS provides for the urban space. On the other hand, the variety indicator summarizes this data, compiling these with the different types of products (lettuces, tomatoes, chard, etc.), which each municipality is offering the system. Its purpose is to show the diversity of the products versus the quantity. Finally, the freshness indicator localizes the area where more fruit and vegetables are grown than other types of agricultural use. These results will be contrasted, in the discussions, against the classical theory of localization of Von Thünen [78-80], whose model distributes agrarian soil use into rings around an urban market based on distance and transportation costs, generating a specialization in the spatial distribution of the system. 
Each foodshed indicator is represented by 4 maps in total, corresponding to ULFS and PLFS in summer and winter.

\subsection{Analysing the Regenerative Features}

The third stage comprises identifying the regenerative features of the LFS in the CMA using the foodshed indicators.

Three features of the Regenerative Food Systems were identified from Dahlberg's work [41,42] in order to delve into the foodshed's set of maps using the regenerative approach: (1) Diversity, (2) Flexibility, and (3) Self-reliance. As Dahlberg never fully elaborated these concepts, a review of the literature has helped to define them, adjusting them to the theoretical framework of this study. Diversity is recognized as both a feature that confronts industrial agriculture, producing a homogenization of diet and embeddedness of local systems in conventional chains [81], and as a social diversity, with a variety of knowledge and diverse economies [82]. Flexibility is recognized as the ability to adapt production to geographical and climatic conditions, adhering to environmental limits [40,47]. Self-reliance is defined as the capacity of a food system to establish itself "from below" and manage its own internal resources and endogenous development potential in economic, socio-cultural, environmental, and political terms, in order to reduce the level of dependence $[41,83]$ while building a strong alternative to agroindustrial food systems [25]. Self-reliance, unlike similar concepts such as self-sufficiency, seeks to achieve the highest level of autonomy possible while understanding the need to be linked to other food networks.

These three features of the regenerative approach could be applied to several dimensions. However, the priority of this study is to identify them within the spatial dimension. For this purpose, three spatial analytical categories were built to read the foodshed indicators maps, comparing the findings of ULFS and PLFS in the CMA.

- Diversity is applied to the spatial analysis of production and accessibility to food diversification within the foodshed of each LFS. The more diverse both rural production and urban accessibility to food spaces are in intensity, variety, and freshness, and the more diverse there are in their rural-urban linkages, the more regenerative potential the LFS have. Diversity requires a cross-sectional analysis of the three foodshed indicators: intensity, variety, and freshness (see Figure 3).

- Flexibility is applied to the spatial analysis of productive diversity of each LFS to geographical and climatic conditions. This implies analysing how foodshed indicators adapt to seasonality, where the more flexible the productive diversity to seasons is, the more regenerative potential the LFS has. Flexibility requires a cross-sectional analysis of the indicators in both seasons: summer and winter (see Figure 3).

- Self-reliance is applied to analyzing the spatial regenerative complementarity of both PLFS and ULFS foodsheds. This analysis was done with the aim of understanding whether both systems together could comprise a stronger urban-metropolitan local and alternative food system, with a higher regenerative potential than each LFS separately. The analysis will compare the geographical foodshed, the diversity along with the flexible regenerative features. The more complementary both LFS are, the more regenerative potential the urban-metropolitan local and alternative food systems, and their supply rural-urban linkages, have. Self-reliance requires a cross-sectional analysis of the indicators in both LFS: ULFS and PLFS (see Figure 3).

This triple cross-sectional analysis looks to identify whether the LFS are operating as RFS in the CMA, restoring or building new and sustainable rural-urban relationships. 


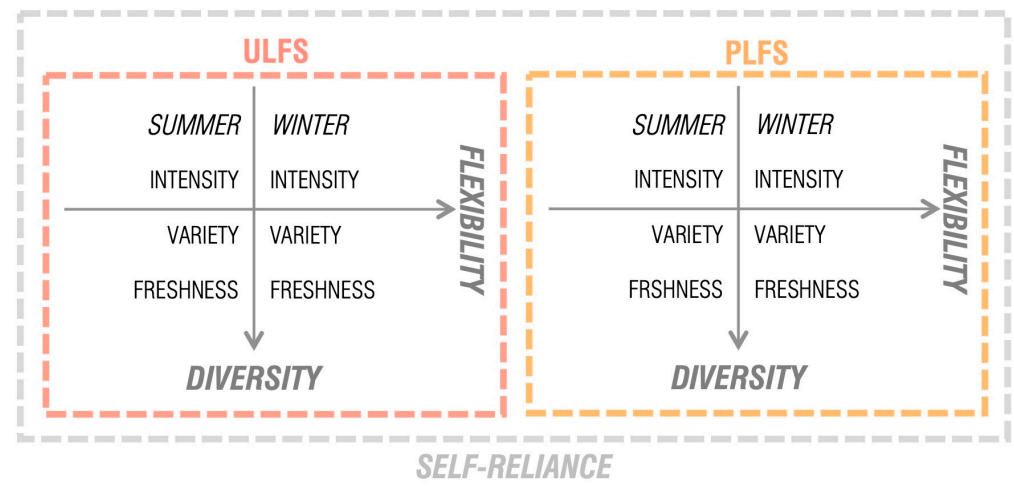

Figure 3. Diagram of the combination of regenerative features and foodshed indicators. ULFS, urban local food system; PLFS, peasant local food system.

\section{Results}

\subsection{Geographical Foodshed}

The geographical foodshed maps of ULFS and PLFS (Figure 4) show both the urban side, or destination, of the food supply and the rural side, or source, of supply. For the urban side, the maps show that the seven urban ULFS points are concentrated in downtown Concepción, while the four urban PLFS nodes are spread throughout Concepción, as the central municipality, Penco and Tomé, as northern coastal municipalities, and Santa Juana, as a fluvial municipality. This spatial distribution of urban points and nodes implies that each system is providing access to fresh, local, and organic food for different kinds of urban populations. While downtown concentrates the services sector, the coastal municipalities from the first and second ring are increasingly becoming dormitory towns of Concepción. The more distant fluvial municipalities, on the other hand, have retained a strong peasant-based nature. However, together, both LFS are feeding a highly diverse urban population.

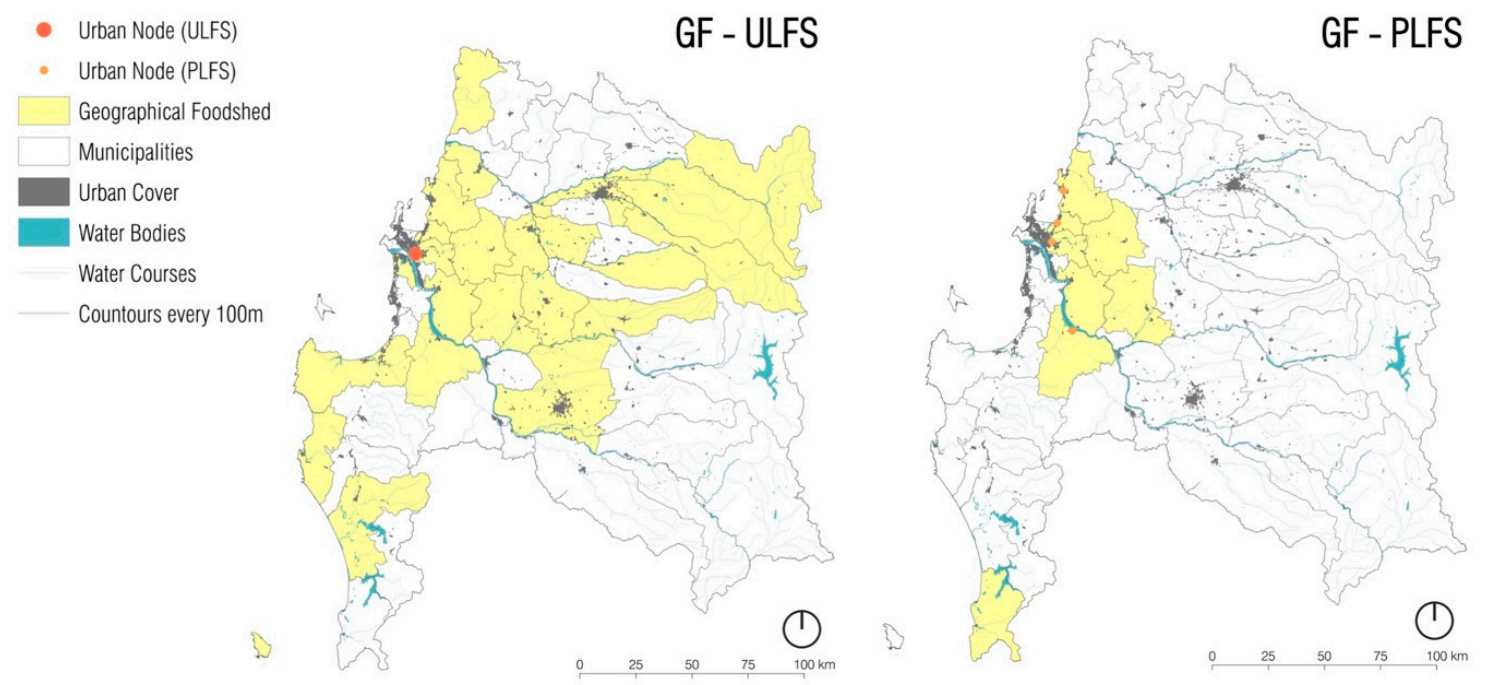

Figure 4. Geographical Foodshed of ULFS and PLFS. GF, geographical foodshed.

On the other side of the system, the geographical foodshed maps show that ULFS has a widespread geographical foodshed, reaching 23 supplier municipalities scattered along the coastal area, the central valley, and northeast municipalities of the Biobio Region. Meanwhile, the PLFS has a compact geographical foodshed concentrated in eight supplier municipalities within the first and second rings around Concepción. This important difference in the scale of both foodsheds will have implications in the kind of agriculture link to each system, because the municipalities from the coast along with the first and second ring are set within the coastal range, while the rest are located in the Central Valley. 
Another implication is related to the geographical proximity of the supplier municipalities and the kinds of foodstuffs that each is supplying to the CMA. While, on the other hand, there is a juxtaposition of both foodsheds within the first and second rings around Concepción that will need to be analyzed using the indicators (Figure 5).

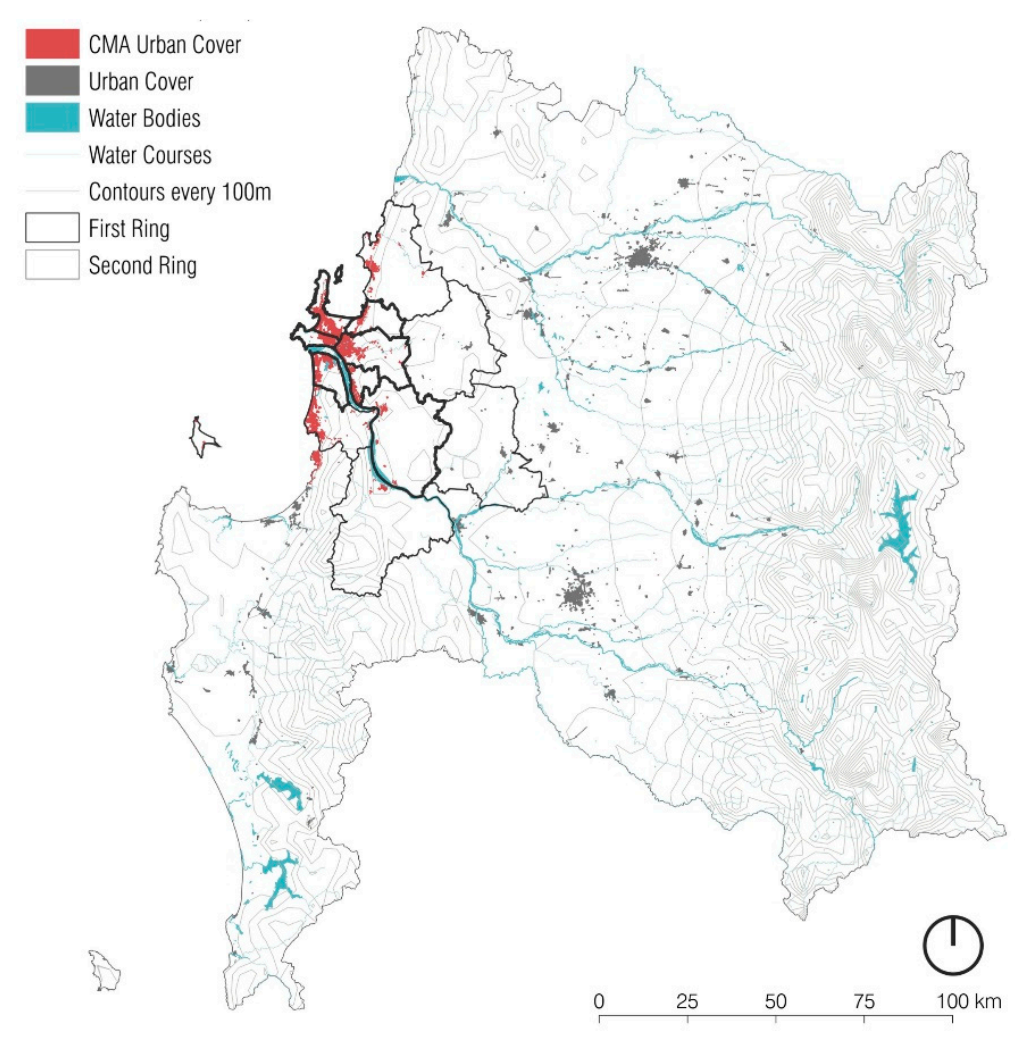

Figure 5. First and second ring of municipalities around Concepción.

\subsection{ULFS and PLFS Foodshed Indicators}

Even though the key results of this part of the process are presented though the foodshed maps, Table 1 presents an overview that lays out the overall data collected in the survey for each LFS. It shows the active urban points, urban nodes, and supplier municipalities of each system in both seasons. It also indicates the amount of foods surveyed (intensity), the amount of different varieties surveyed (variety), and the percentage of fresh food for each LFS and in both seasons. The following analysis of the foodshed maps will use Table 1 below, to compare quantitative data with spatial analysis.

Table 1. Overall data of ULFS and PLFS foodshed indicators.

\begin{tabular}{ccccc}
\hline LFS & \multicolumn{2}{c}{ ULFS } & \multicolumn{2}{c}{ PLFS } \\
\hline Season & Summer & Winter & Summer & Winter \\
\hline Urban points & 7 & 7 & 46 & 46 \\
Urban nodes & 0 & 0 & 4 & 4 \\
Supplier municipalities & 23 & 23 & 8 & 8 \\
Intensity & 216 & 166 & 736 & 428 \\
Variety & 180 & 152 & 208 & 157 \\
Freshness & $39.8 \%$ & $27.7 \%$ & $60.1 \%$ & $46.7 \%$ \\
\hline
\end{tabular}

\subsubsection{Intensity Foodshed Indicator}

Table 1 shows that the PLFS foodshed supplying the urban side is three times more intense than the ULFS foodshed. This means that the four PLFS urban nodes are receiving between 4-6 times more 
foods than the seven ULFS urban points. In addition, the Intensity Foodshed Indicator Maps (Figure 6) shows that the generally lower intensity of ULFS is diluted and spread within the scattered foodshed, producing a homogeneous redistribution of the food production across the 23 municipalities, which oscillates between one and ten foodstuffs per municipality. However, the case of PLFS is different, since the high intensity surveyed on the urban side is also present in the foodshed. The productive farmland is concentrated within just seven supplier municipalities located in the first and second ring around Concepción, which are providing between 50 and 150 foods per municipality throughout the year. In summary, the PLFS foodshed is more intense both on the urban and the supplier side, while the ULFS foodshed is less intense on both sides of the system. This means that the rural-urban linkages that PLFS are fostering, are stronger than those that ULFS are actually developing.

\begin{tabular}{|l}
\hline Intensity (nr. of products) \\
Very Low [1 - 10] \\
Low [10 - 50] \\
Medium [50 - 100] \\
High [100 - 150] \\
Very High [150 - 200] \\
$\square \quad$ Urban Node (ULFS) \\
Urban Node (PLFS) \\
$\square$ CMA \\
$\square$ Municipalities \\
Urban Cover \\
Water Bodies \\
Water Courses
\end{tabular}
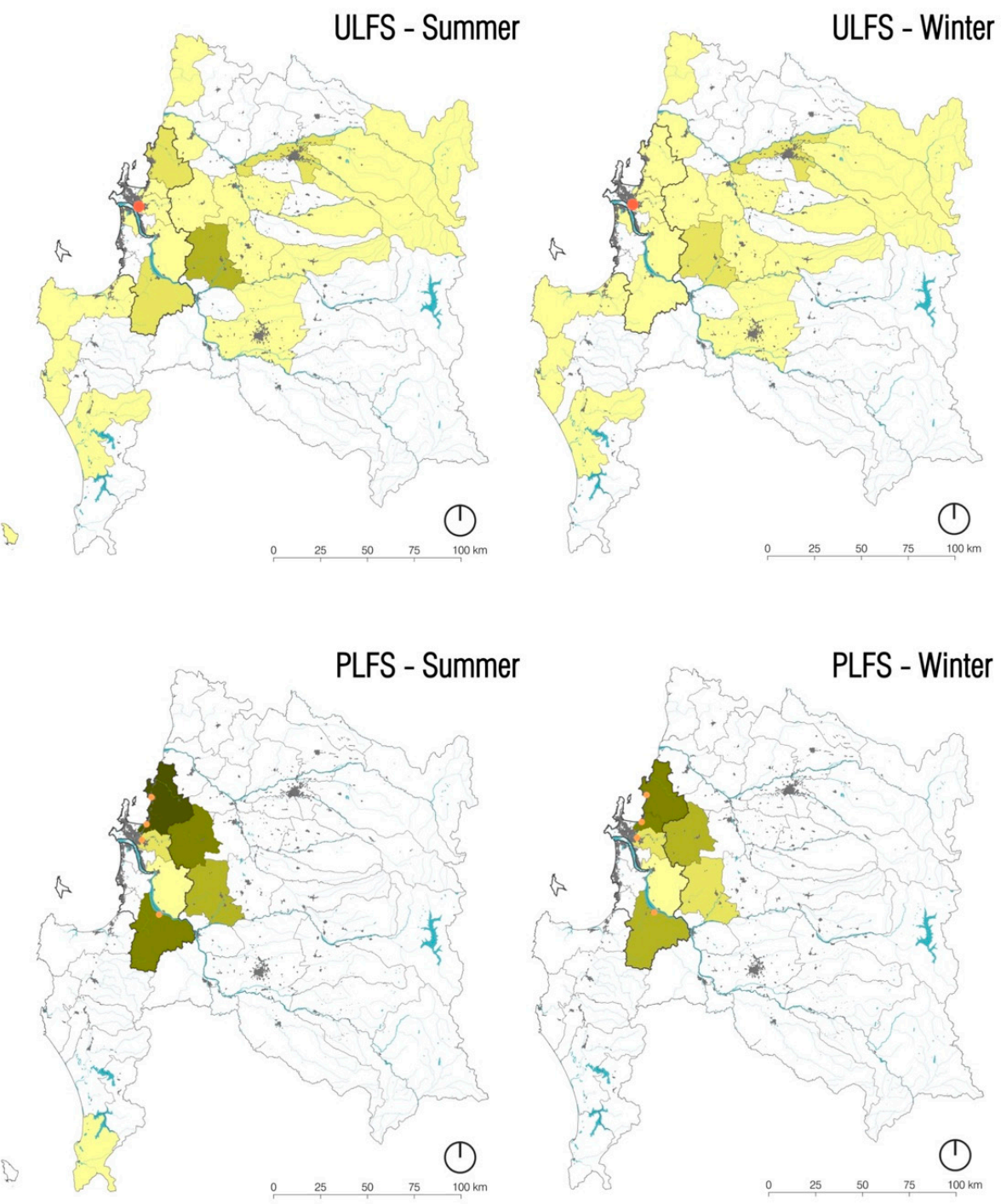

Figure 6. Intensity Foodshed Indicator Maps.

Conversely, the maps show that both LFS are more intense in summer than in winter, with the PLFS particularly intense. However, during winter, levels of intensity are maintained at over $50 \%$ of summer levels, keeping both systems active in this lean season.

One of the targets of this indicator was to identify the intensity foodshed scale of each system. Thus, for the PLFS, the intensity scale is the entire foodshed because of the high intensity of the urban-rural supply relationships. However, for the ULFS, it is not possible to identify the intensity scale because of the low intensity of the links within both sides of the system. 


\subsubsection{Variety of Foodstuffs Foodshed Indicator}

Table 1 shows that the PLFS foodshed is supplying the urban nodes with twice as much variety as the ULFS foodshed. This is replicated on the Variety of Foodstuffs Foodshed Indicator Maps (Figure 7), where PLFS supplier municipalities, on average, provide four times more food variety than ULFS municipalities. In both cases, the first and the second ring of supplier municipalities around Concepción provide a greater variety of foodstuffs than the rest of supplier municipalities, with the ULFS at an average of 5-10 foods and the PLFS, 20-100 foods. In summary, PLFS and ULFS have a similar variety, but the first concentrates this variety within the seven supplier municipalities, resulting in a high variety, and the second is spread over 23 municipalities, resulting in a medium variety.

\begin{tabular}{|c|c|}
\hline & Very Low [1 - 5] \\
\hline & Low [5 - 20] \\
\hline & Medium [20 - 40] \\
\hline & High [40 - 60] \\
\hline & Very High [60 - 100] \\
\hline$\bullet$ & Urban Node (ULFS) \\
\hline . & Urban Node (PLFS) \\
\hline & CMA \\
\hline & Municipalities \\
\hline & Urban Cover \\
\hline & Water Bodies \\
\hline & Water Courses \\
\hline
\end{tabular}
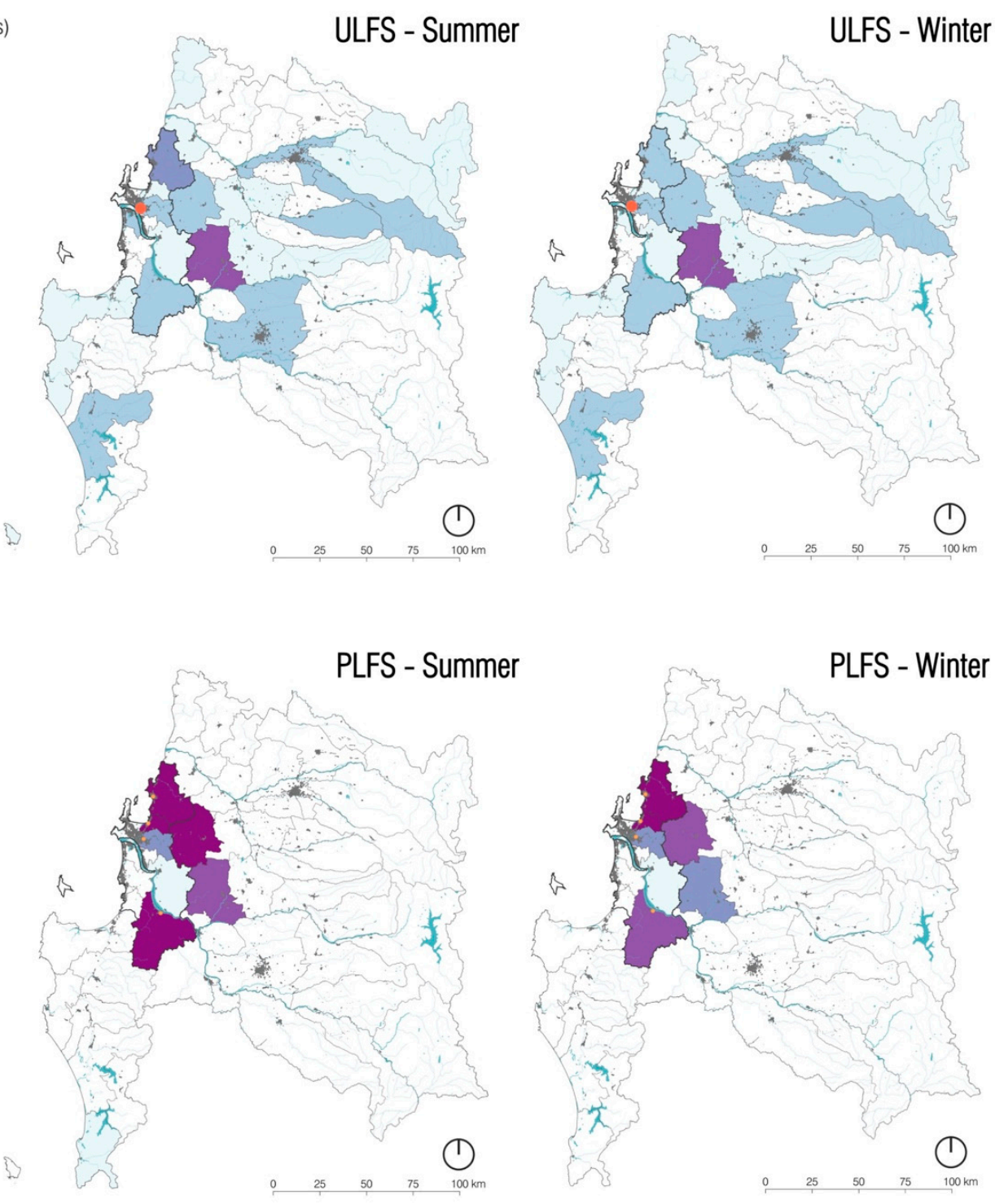

Figure 7. Variety of Foodstuffs Foodshed Indicator Maps.

Table 1 shows that the variety levels of PLFS are similar to ULFS in winter and slightly higher for PLFS in the summer season. Complementarily, the maps demonstrate that there is a slight increase in foodstuff variety in several municipalities in summer in both systems, but without an increase in the number of supplier municipalities.

One of this indicator's targets was identifying the variety foodshed scale of each system. Here, six of eight municipalities are providing a high variety of foodstuffs for PLFS, meaning they have a higher productive variety of their farmland. The scale of this system comprises municipalities within 
the foodshed's first and second ring. Conversely, the ULFS municipalities that are providing a medium variety are scattered across the Bio-Bio Region, so the variety scale for this system is regional.

\subsubsection{Freshness Foodshed Indicator}

Data from Table 1 shows that PLFS supply a higher percentage of fresh foodstuffs to the city (50-60\%) than ULFS (30-40\%). The Freshness Foodshed Indicator Maps (Figure 8) also show that supplier municipalities from the first and second ring are the main fresh food providers to both systems in both seasons. While PLFS are constrained to that limit, ULFS has more supplier municipalities scattered in the regional context that mainly provide processed foods to the city.

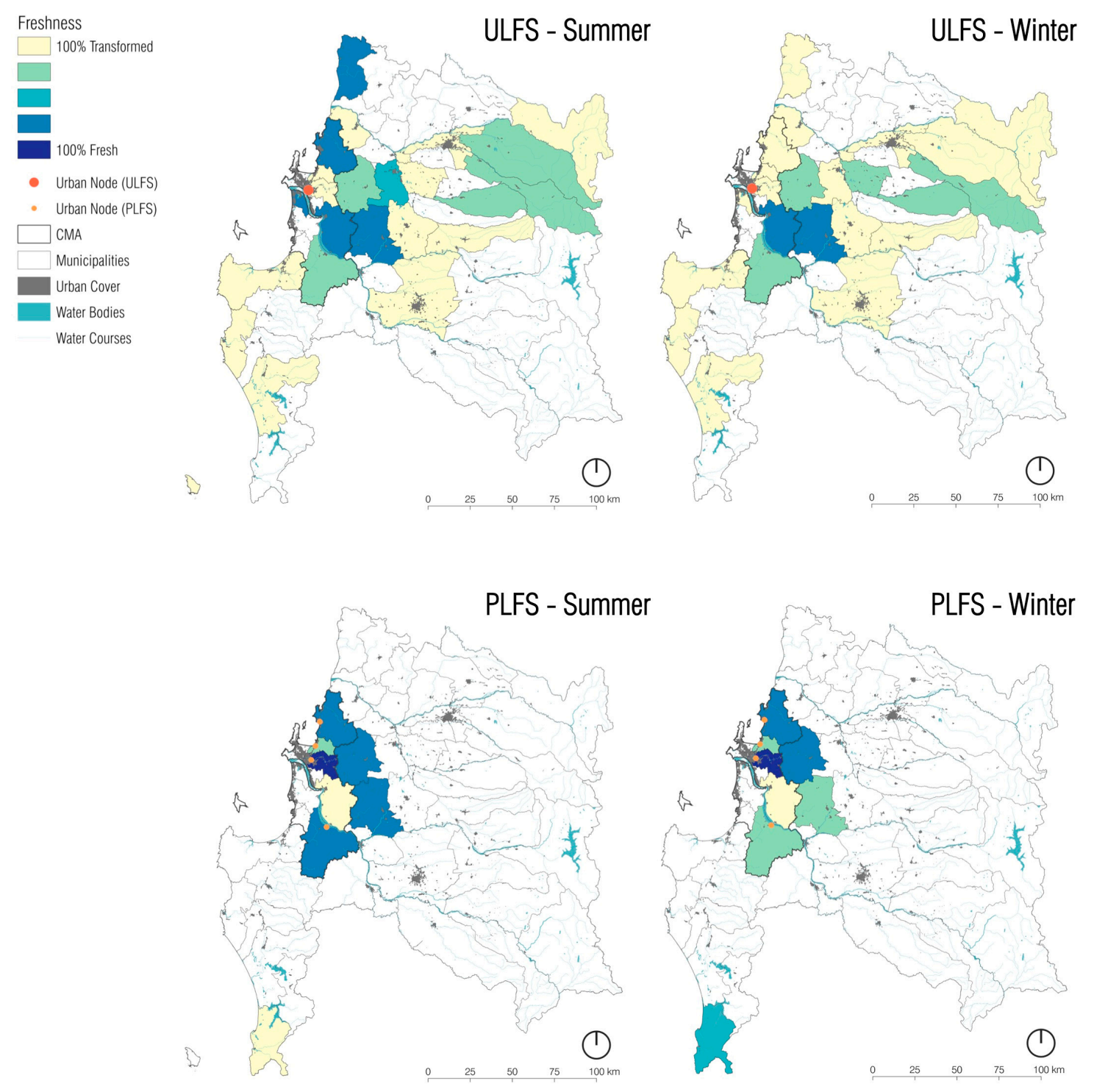

Figure 8. Freshness Foodshed Indicator Maps.

Data show that there is a $10 \%$ increase of fresh foodstuffs in summer for both systems. The foodshed shows that ULFS increase their major supplier municipalities from two to five in summertime, while PLFS increase from three to five.

One of this indicator's goals was identifying the freshness foodshed scale of each system. In this case, both systems share the same freshness foodshed scale, which is confined to the two rings of municipalities around Concepción. 


\subsection{Regenerative Features of ULFS and PLFS}

\subsubsection{Diversity}

As seen before, the geographical foodshed scale is different for each LFS. The PLFS has a compact foodshed, while the ULFS works on a scale of the Biobio Region. This means that ULFS is linked to a more diverse production method because of the more varied geographical and climatic conditions of its foodshed.

When considering the analysis of productive diversification, although both PLFS and ULFS present medium and varied levels on their foodshed variety maps, a cross-sectional analysis with the intensity maps shows that the PLFS has a high spatial productive diversity in its compact foodshed, while the ULFS has a low spatial productive diversity because of its low intensity in its wider foodshed. Also, foodshed indicators related to intensity and freshness, together, show that diversity of the supplier municipalities, from the first and second rings, is mainly related to fresh foods in both LFS. For the case of ULFS, beyond this second ring, with some exceptions, the low diversity is mainly related to processed foods. This implies that ULFS supplier municipalities are more specialized in the type of foodstuffs they provide in relation to geographical distance (fresh food closer and processed food farther), while PLFS supplier municipalities, from the first and second ring, provide both of the types of foodstuffs (fresh and processed) collected in the surveys. In this sense, ULFS more faithfully follows Von Thünen's theory of geographical proximity. In summary, both systems offer different kinds of spatial and functional distribution when it comes to production diversification on the supply side.

However, with regard to the accessibility to urban food spaces, PLFS presents more diversity. The spatial distribution of the PLFS' four farmer markets shows that they are oriented to different kinds of commensal-citizens. Concepción's urban node focuses on supplying people from the central part of the city who want to get fresh and local food that comes mainly from other supplier municipalities. This occurs because Concepción has almost no farmland. The other urban nodes have a more locally based focus, building a closer proximity relationship. The northern coastal farmer markets provide access to food for people who live in those municipalities, even though the people are functionally connected to Concepción. While the fluvial area's urban node provides food to people who usually live and work in the municipality. The ULFS urban points, meanwhile, are concentrated downtown, orienting their local food to the high heterogeneity of people passing through this main service centre. All in all, on the urban side, both systems offer a wide range of diversity in accessibility to food spaces.

Overall, both LFS present a diversification of production and accessibility to food spaces, albeit each of these has different spatial expressions in their diversity. The supply rural-urban relationships that each LFS fosters are (re)connecting this city's diverse accessibility to food spaces and the countryside's diverse production spaces in complex and distinctive ways. This is resulting in the regeneration of the rural-urban linkages that were damaged or non-existent just a few years ago.

\subsubsection{Flexibility}

As shown on Table 1 and in the foodshed indicators, both systems are more intense, more varied, and more focused on fresh foodstuffs in summer, increasing the levels of the three indicators for the supplier municipalities. A key aspect is that both systems are keeping their foodsheds active in the lean season, just working in the same supplier municipalities, with a lower level of the three indicators.

There is a $20 \%$ increase for ULFS and nearly $30 \%$ for PLFS in the variety of foodstuffs in summer. The percentage of freshness s also increases in summer, by more than $10 \%$ for ULFS and nearly $15 \%$ for PLFS. This means that there are summer varieties of fresh food in the peak season. However, these quantitative data cannot be read clearly on the variety and freshness foodshed maps because the data increase is spread throughout the supplier municipalities, and what is perceived is just a slight increase of two or three supplier municipalities, with higher levels in both indicators. This spatial distribution in the increase in variety also means that all the supplier municipalities are improving their productive diversity instead of this phenomenon being concentrated in only a few. 
Overall, both LFS present, in general terms, a relevant adaptation to the seasonality, one which is equally distributed throughout the farmland of each foodshed. Both LFS have been able to sustain food production with sustainable practices over time (in some cases nearly 10 years), adapting to peak seasons by increasing the variety of foodstuffs and the percentage of fresh food, maintaining a reasonable level of intensity all-year-round, by guaranteeing freshness as a result of the close proximity from origin to the urban points. LFS have also adapted their productive diversity to the geographical and climatic conditions, resulting in a regeneration of the rural-urban linkages over the last few years.

\subsubsection{Self-reliance}

The analysis of potential complementarity is done by comparing the dynamics of both LFS in the geographical foodshed, the diversity and the flexibility features. The geographical foodshed showed the different scales of both systems. This implies that ULFS, with a more extensive foodshed, can incorporate more diverse climatic characteristics increasing both the production methods and the amount of local food varieties. On the other hand, diversity showed that both systems offer a different spatial and functional distribution of production diversification. While ULFS has a more specialized foodshed of its wider geographical foodshed, PLFS concentrates a more compact and diverse foodshed. Besides, while PLFS are mainly fresh food oriented, ULFS mostly subsists from processed foods. Thus, both have a potential spatial and functional complementarity. In relation to the diversification of the food access spaces on the urban side, both systems are oriented to different kinds of urban population, hence their spatial concentration and distribution throughout the metropolitan area answers this point. Finally, flexibility showed that both of the LFS are using the same adaptation strategy to seasonality in order to keep a medium level of production in winter without using GMO's. Table 2 compares the main topics discussed above showing the differences of both LFS that can be also understood as complementary.

Table 2. Comparative table of potential complementarity of ULFS and PLFS.

\begin{tabular}{ccc}
\hline & ULFS & PLFS \\
\hline Geographical foodshed & $\begin{array}{c}\text { Wide } \\
\text { Diverse geographical and } \\
\text { climatic characteristics }\end{array}$ & $\begin{array}{c}\text { Compact } \\
\text { Specific geographical and } \\
\text { climatic characteristics }\end{array}$ \\
\hline $\begin{array}{c}\text { Diversity 1. } \\
\text { Diversification of production spaces }\end{array}$ & $\begin{array}{c}\text { High productive diversity } \\
\text { Specialized foodshed } \\
\text { Processed food oriented }\end{array}$ & $\begin{array}{c}\text { Low productive diversity } \\
\text { Diverse foodshed } \\
\text { Fresh food oriented }\end{array}$ \\
\hline Diversity 2. & $\begin{array}{c}\text { Concentrated urban point } \\
\text { Open to heterogeneous citizens }\end{array}$ & $\begin{array}{c}\text { Dispersed urban nodes } \\
\text { Citizens segmented by location }\end{array}$ \\
\hline Fiversification of food access spaces & \multicolumn{2}{c}{ Keeps the level of production all-year-round } \\
\hline \multicolumn{2}{c}{}
\end{tabular}

Overall, this analysis shows that although the geographical foodshed and diversity of ULFS and PLFS have a different spatial and functional behaviors, they do not present incompatibilities, and both look to build a real alternative to the industrial food systems. Flexibility has shown that its main aim is not to ensure complementarity, but rather system stability all-year-round. For that reason, it is possible to understand that both foodsheds have a potential complementarity to create synergies and to strengthen the whole alternative system. Currently, these LFS operate in parallel within the metropolitan and regional space. This fact in itself implies that the urban-metropolitan local and alternative food system is stronger, more resilient, has a higher potential of self-reliance and a higher regenerative potential for enhancing rural-urban linkages. 


\section{Discussions}

\subsection{Local Scale for the Local Food Systems}

The analysis of the CMA case has shown that the characterization of the foodshed through the three designed indicators: (1) intensity, (2) variety of foodstuffs, and (3) freshness can bring to light the local scale of an LFS. What is advocated here, set against other definitions of "localness" stated hitherto by distance between producers and consumers, social constructions, and cultural elements $[31,84,85]$, is that "local" is the critical convergence of the three scales extracted from the foodshed indicators, namely (1) the intensity scale, (2) the variety scale, and (3) the freshness scale. This implies that local is anchored to the food supply support structure and, concretely, to the area that holds a stronger and more consolidated supply linkage with the urban side. Under this premise, local can be considered the critical scale of a supply rural-urban relationship within an LFS foodshed. This scale can be at its top, the geographical foodshed of the system and at its bottom, non-existent, because the indicator levels are very low.

When the foodshed is compact and intense, as in the case of PLFS in CMA, identifying the local scale boundary, considering all the municipalities with a high intensity, high variety and high percentage of fresh food, is an easy task. But, when the foodshed is scattered and weak, as in the case of ULFS in CMA, a critical analysis should be made to identify the local scale.

Although the three indicators are important for identifying the "localness" of an LFS, the freshness scale is key. This leads to the classical Von Thünen theory of localization [78,86], where the high intensity production, namely the fresh products, should be located in the first ring, while the other rings should include forms of primary production that are less intensive [87]. The land use pattern in the Biobio Region is complex because of the presence of major forestry companies, agroindustry, and energy production that may affect the distance theory assumptions. However, this model is still useful when it comes to understanding the (re)newed linkages between contemporary cities and their hinterlands related to small scale agriculture.

In the case being studied, the ULFS foodshed has a classical spatial distribution of Von Thünen's model, with specialized radii around the city. The first two rings of municipalities mainly supply fresh food, while the more distant farmland mainly provides processed food. However, PLFS have a more compact foodshed, providing both fresh and processed foods, which does not follow Von Thünen's criteria of specialization. The nature of this differentiation in the foodshed's specialization (and also in its geographical extension) may be linked to the conditions that underpin each LFS. PLFS in CMA are a place-based peasant movement, rooted to concrete metropolitan farmlands. This community supplies a variety and intensity of fresh and processed foodstuffs to the urban population that adapts to their human, economic, and territorial resources. However, ULFS are an urban movement, reconnecting the urban world with small agroecological projects spread all over the Biobío Region [33], providing a lower intensity of products and following Von Thünen's diagram as an urban-centric distribution. Their building network mechanisms are also place-based but not rooted to a concrete farmland area, and while the network's boundaries are confined to a physical distance, they are considered ethical and accessible. In both LFS, as the first and second ring of supplier municipalities concentrate a higher supply of fresh food (this freshness scale is key), this boundary should be considered the minimum scale for the LFS when it comes to making the analysis. The variety and intensity scales, meanwhile, could include new municipalities later.

A potential increase of urban alternative food volume, within ecological limits, should preferably result in an increased intensity and variety within the current local foodshed. It should not lead to increasing the size of the local critical area, because it could overlap with other local foodsheds and compete for productive resources [88].

Finally, this local critical scale of a bottom-up LFS seems to be a suitable area, where it is possible to think about integrative food policies that include the preservation of farmland, rural development, reinforce organic farming, increased productive diversity and flexibility, and a (re)link with the 
commensal-citizens [47]. All of this is done with the aim of regenerating the LFS and the supply urban-rural relationships using a complementary top-down strategy.

\subsection{Regenerative Food System to Restore Rural-Urban Relationships}

The application of the method to analyse whether LFS in CMA have regenerative potential to restore or build new sustainable rural-urban relationships has shed light on some key aspects that show how an LFS is being converted into a potential RFS.

A first key aspect is that each LFS should have an inherent diversity both in accessibility to food and productive spaces and in the supply relationships that are (re)connecting them. The existence of this diversity gives the LFS the potential to become an RFS. The analysis of diversity in the CMA, has revealed the existence of diverse territorial dynamics in the PLFS and ULFS foodsheds. This diversity is the result of different communities, accessibility to food spaces, production spaces, and cultures, [33] and is related to other forms of diversity, such as agroecology and food sovereignty principles [36] (Cid and Latta, 2015). In this sense, spatial dimension analysis can be the main axis to shed light on the LFS' social diversity, variety of knowledge, and diverse economies [82]. The multidimensional diversity of LFS confronts the industrial food systems, the threat of homogenization of natural ecosystems and cultural landscapes [89], and the local system's embeddedness in industrial chains [81].

A second key aspect is that LFS should adapt to external changes without decreasing their indicator levels all-year-round. This adaptation to natural limits provides regenerative potential to LFS. Usually, flexibility is related to the resilience concept [90,91], but for this study, flexibility is understood as the capacity of adaptation of the LFS to natural limits, which provides a regenerative potential. The spatial analysis of flexibility in the CMA has explored adaptive strategies to face seasonal changes without turning to agrochemicals or GMOs and has revealed that both systems are using the same strategy to adapt to seasonality. The method designed has considered the analysis of the dynamics of both LFS in peak and lean seasons. This approach was useful to capture the entire variety of each system's productive capacity, and to confirm that they are sustainable over time. The capacity of LFS to keep their sustainable practices in line with their principles, requires maintaining a certain degree of flexibility. Future applications of the method should explore, under regenerative assumptions, new dimensions related both to the analysis of the adaptive strategies to face seasonality in accessibility to food spaces, and the system's capacity to overcome natural disasters, market crises, or institutional changes.

A third key aspect is that the existence of multiple LFS in an urban-metropolitan area could allow operating both spatially and functionally. The urban local food system will be able to self-enhance and will have more regenerative potential. The analysis of self-reliance in the CMA has revealed the potential complementarity between PLFS and ULFS in creating a stronger alternative to face the agroindustrial food system [92]. Both systems have self-developed from the bottom-up over the last ten years, managing their sociocultural, environmental, and territorial resources, while reducing their level of dependence on industrial systems and capitalism $[41,83]$. As it was not possible to analyse the dimension of the self-reliance of an LFS with the data collected, a more integrative definition of the regenerative feature was adopted. Dahlberg [41,43] clarifies that self-reliance is not a synonym of self-sufficiency, but rather the capacity of the system to connect to other systems to procure its necessities, without creating dependence. Therefore, the aim of the method was to focus on these assumptions and to analyse the capacity of the local food system to get stronger. Future developments of the method should be centred on analysing the (in)dependence of LFS in regard to the industrial system.

A fourth key aspect is that the local scale has shown itself to be a key element when determining the regenerative potential of an LFS because its farmland is the main support structure of the LFS' regenerative potential. This area provides a clear geographical delimitation of what constitutes "local" [93] under regenerative assumptions. The analysis of LFS food traceability in the CMA has resulted in a representation of the productive area that is actually connected to the accessibility to food urban spaces through intensity, variety, and freshness supply relationships, namely the foodshed. This analysis contributes to previous research $[48,60]$ with a quantitative characterization of the supply 
linkages, which outlines the local boundaries. The "local" scale advocated here is the area of the foodshed with high levels in the three foodshed indicators and more consolidated linkages. The lack of this scale implies that LFS do not have regenerative potential. This could have happened for several reasons. First, there is no farmland left around the city due to urban or other dynamics. Second, there is no LFS operating at the city-region scale, because there are no bottom-up alternative movements. Finally, third, the supply relationships are very limited.

Hence, an RFS is an LFS that meets the regenerative features, has a local foodshed scale, and mobilizes its sociocultural, environmental, economic, and territorial resources from the bottom up to enhance the urban-metropolitan local and alternative food systems and to restore or build new sustainable, resilient, and self-reliant rural-urban relationships. This approach is particularly relevant in middle-income countries like Chile that are fully embedded in a neoliberal economical system where, even though cities have broken off their rural-urban relationships [94], there are still remnants of peasant and small-scale agriculture-remnants that are currently reformulating and whose aspiration is to (re)connect with the city [95].

\section{Conclusions}

This study has sought to shed light on the regenerative potential of LFS. With a new methodological proposal, the spatial analysis made through the foodshed and its quantitative and qualitative characterization has evaluated whether LFS are regenerating rural-urban relationships in the CMA, despite the high level of industrialization of the Chilean food systems and their agriculture. The results highlight that LFS in the CMA are certainly restoring relationships between the city and its surrounding farmland by establishing new and renewed supply linkages.

The use of the foodshed as a methodological tool for analysing the spatial dimension of LFS has been very relevant when it comes to showing their dynamics and impacts, both individually and together, as part of the larger urban-metropolitan local and alternative food options in the CMA. The three quantitative foodshed indicators have been very useful in identifying the differences between PLFS and ULFS and determining their "localness". The first indicator, Intensity, was a determining indicator because it indicates the strength of supply linkages between the foodshed and the city. The second, Variety of foodstuffs, provided a snapshot of the foodshed's productive diversity. Meanwhile, the third indicator, Freshness, was key in identifying the system's "localness". Each indicator provided a scale for the intensity, variety, and freshness of the LFS, while a critical intersection of scales formed the LFS' "local" scale. This scale is especially relevant because it is the critical area with the supporting structure of the supply rural-urban relationships.

With regard to the regenerative character of LFS, the three regenerative features were qualitatively analysed through a cross-sectional analysis of the foodshed indicators. The LFS' diversity feature allowed identifying the diversification of production and accessibility to food urban spaces. Their flexibility feature identified the capacity of each system to adapt to seasonal changes. The LFS' self-reliance feature was analysed through the potential regenerative complementarity of both PLFS and ULFS foodsheds. The results demonstrated that both LFS have regenerative potential, but PLFS already has a more active role in restoring the urban-rural linkages. On the other hand, ULFS are a complement inside the $\mathrm{CMA}$, but still need to enhance their relationship with their supplier municipalities to reinforce the regenerative character.

The proposed method has two major limitations related to complications in collecting two pieces of data: the volume of products and the identification of the producers. The former restricts the intensity data of the urban-rural link to the number of different products that are commercialized, losing the real data about the flow's strength. The latter restricts a cross-analysis between the two systems to understand whether overlaps or interactions are being produced between them.

Finally, the proposed method has been successful as an exploratory attempt to characterize the regenerative potential of RFS. The analysis addressed from the spatial dimension of food traceability has proven to be a solid base to outline RFS. However, it will be necessary to investigate other dimensions 
of the LFS in order to enrich the theoretical framework of regenerative food systems, such as the consumption and demand, territorial conflicts, the waste cycle, or the institutional framework.

Author Contributions: A.Z.-M., as principal investigator, conceived the project and designed the methodology. I.T.-G. performed the collection and processing of the data and generated the foodshed indicator maps. A.Z.-M. and I.T.-G. analysed the data and wrote the paper. A.Z.-M., I.T.-G., and A.M.-M. reviewed the comments and re-wrote the paper.

Funding: This research was funded by Universidad del Bio-bio (DIUBB-1704012/I), Concepción, Chile. The publication is funded by the Universidad del Bio-Bio and the Project Asignable 224.773 from the Pontificia Universidad Católica de Valparaíso.

Acknowledgments: We appreciate the contribution of the people and organizations involved in the farmer markets, organic shops and local restaurants of the Concepción Metropolitan Area, who have inspired this research and shared their time and experience with us. The field work was carried out by students during their Architecture Degree research seminar within the framework of this project at the University of Bio-Bio: Camila Vivallo, Camila Aránguiz and Felipe Garrido whom we thank for their dedication and commitment to the project. We also appreciate the constructive comments made by Valeriá Paül and the proofreading made by Kevin Wright.

Conflicts of Interest: The authors declare no conflict of interest. The funders had no role in the design of the study; in the collection, analyses, or interpretation of data; in the writing of the manuscript, or in the decision to publish the results.

\section{References}

1. Kennedy, C.; Cuddihy, J.; Engel-Yan, J. The changing metabolism of cities. J. Ind. Ecol. 2007, 11, 43-59. [CrossRef]

2. Torreggiani, D.; Dall'Ara, E.; Tassinari, P. The urban nature of agriculture: Bidirectional trends between city and countryside. Cities 2012, 29, 412-416. [CrossRef]

3. Soja, E. Postmetropolis: Critical Studies of Cities and Regions; Blackwell Publishing: Los Angeles, CA, USA, 2000.

4. Jacobs, J. The Death and Life of Great American Cities; Random House: New York, NY, USA, 1961; ISBN 978-0679741954.

5. Mumford, L. The City in History: Its Origins, Its Transformations and Its Prospects; Harcourt, Brace, and World: New York, NY, USA, 1961; ISBN 978-0156180351.

6. Wiskerke, J.S.C. On places lost and places regained: Reflections on the alternative food geography and sustainable regional development. Int. Plan. Stud. 2009, 14, 369-387. [CrossRef]

7. Curran-Cournane, F.; Cain, T.; Greenhalgh, S.; Samarsinghe, O. Attitudes of a farming community towards urban growth and rural fragmentation-An Auckland case study. Land Use Policy 2016, 58, 241-250. [CrossRef]

8. Delgado, M. El sistema agroalimentario globalizado: Imperios alimentarios y degradación social y ecológica. Econ. Crit. 2010, 10, 32-61.

9. Butt, A. Exploring Peri-urbanisation and agricultural systems in the Melbourne region. Geogr. Res. 2013, 51, 204-218. [CrossRef]

10. Piorr, A. (Ed.) Peri-Urbanisation in Europe: Towards European Policies to Sustain URBAN-RURAL Futures; Forest \& Landscape, University of Copenhagen: Frederiksberg, Copenhagen, Denmark, 2011; ISBN 9788779035348 8779035345.

11. Maturana, F. ¿Ausencia de planificación urbana en Chile? Algunas reflexiones. Cybergeo Eur. J. Geogr. 2017, 43. Available online: http://journals.openedition.org/cybergeo/28064 (accessed on 17 December 2018).

12. Canales, A.; Canales, M. De la metropolización a las agrópolis. El nuevo poblamiento urbano en el Chile actual. Polis 2013, 12, 31-56. [CrossRef]

13. Dockemdorff, E.; Rodríguez, A.; Winchester, L. Santiago de Chile: Metropolization, globalization and inequity. Environ. Urban 2000, 12, 171-183. [CrossRef]

14. Steel, C. Hungry City. How Food Shapes Our Lives; Chatto \& Windus, Vintage: London, UK, 2008; ISBN 978-0701180379.

15. Bryant, C.R.; Johnston, T.R.R. Agriculture in the City's Countryside; University of Toronto: Toronto, ON, Canada, 1992; ISBN 1-85293-027-6. 
16. Oosterveer, P.; Sonnenfeld, D.A. Food, Globalization and Sustainability; Routledge: New York, NY, USA, 2012; ISBN 978-1849712613.

17. Sundkvist, Å.; Milestad, R.; Jansson, A. On the importance of tightening feedback loops for sustainable development of food systems. Food Policy 2005, 30, 224-239. [CrossRef]

18. Tsuchiya, K.; Hara, Y.; Thaitakoo, D. Linking food and land systems for sustainable peri-urban agriculture in Bangkok metropolitan region. Landsc. Urban Plan. 2015, 143, 192-204. [CrossRef]

19. Knight, L.; Riggs, W. Nourishing urbanism: A case of a new urban paradigm. Int. J. Agric. Sustain. 2010, 8, 116-126. [CrossRef]

20. Tedesco, C.; Petir, C.; Billen, G.; Garnier, J.; Personne, E. Potential for recoupling production and consumption in peri-urban territories: The case-study of the Saclay plateau near Paris, France. Food Policy 2017, 69, 35-45. [CrossRef]

21. Fonte, M. Knowledge, food and place. A way of producing, a way of knowing. Sociol. Rural. 2008, 48, 200-222. [CrossRef]

22. Breitbach, C. The geographies of a more just food system: Building landscapes for social reproduction. Landsc. Res. 2008, 32, 533-557. [CrossRef]

23. McKenzie, F.H.; Stehlik, D. Futures for the Wheatbelt-Is 2030 already here? Aust. J. Agric. Res. 2005, 56, 537-551. [CrossRef]

24. Dubbeling, M.; Carey, J.; Hochberg, K. The Role of Private Sector in City Regions Food Systems. Analysis Report; RUAF Foundation: Leusden, The Netherlands, 2016.

25. Feagan, R. The place of food: Mapping out the 'local' in local food systems. Prog. Hum. Geogr. 2007, 31, 23-42. [CrossRef]

26. Jennings, S.; Cottee, J.; Curtis, T.; Miller, S. Food in an Urbanized World. The Role of City Region Food Systems in Resilience and Sustainable Development; 3Keel and Prince of Wales's International Sustainability Unit: London, UK, 2015.

27. Brunori, G.; Galli, F.; Barjolle, D.; Van Broekhuizen, R.; Colombo, L.; Giampietro, M.; Kirwan, J.; Lang, T.; Mathijs, E.; Maye, D.; et al. Are local food chains more sustainable than food chains? Considerations for assessment. Sustainability 2016, 8, 449. [CrossRef]

28. Paül, V.; McKenzie, F. Peri-urban farmland conservation and development of alternative food networks: Insights from a case-study area in metropolitan Barcelona (Catalonia, Spain). Land Use Policy 2013, 30, 94-105. [CrossRef]

29. Martínez, S.; Hand, M.; Da Pra, M.; Pollack, S.; Ralston, K.; Smith, T.; Vogel, S.; Clark, S.; Lohr, L.; Low, S.; et al. Local Food Systems. Concepts, Impacts and Issues; Economic Research Report Number 97; United States Department of Agriculture: Washington, DC, USA, 2010.

30. Hinrichs, C. Fixing food with ideas of "local" and "place". J. Environ. Stud. Sci. 2016, 6, 759-764. [CrossRef]

31. Eriksen, S. Defining local food: Constructing a new taxonomy-Three domains of proximity. Acta Agric. Scand. B-S P. 2013, 63, 47-55. [CrossRef]

32. Duarte, B. Regenerative development-Building evolutive capacity for healthy living systems. Int. J. Des. Nat. Ecodyn. 2018, 13, 315-323. [CrossRef]

33. Zazo, A.; Troncoso, I. Outlining the alternativeness of urban and peasant food networks in the global south. A case study in the concepción metropolitan area (Chile). In Infinite Rural Systems in a Finite Planet: Bridging Gaps towards Sustainability; Paül, V., Lois, R., Trillo, J.M., McKenzie, F., Eds.; Universidad de Santiago de Compostela Publicaciones: Santiago de Compostela, Spain, 2018; pp. 67-76. ISBN 978-84-16954-89-6.

34. Knieling, J.; Jacuniak-Suda, M.; Obersteg, A. Urban-rural partnerships and governance of peri-urban areas in a European perspective. Towards regenerative regions. In Peri-Urban Areas and Food-Energy-Water Nexus; Colucci, A., Magoni, M., Menoni, S., Eds.; Springer: Cham, Switzerland, 2017. [CrossRef]

35. Proctor, F.; Berdegué, J. Food Systems at the Rural-Urban Interface; Working Paper Series N¹94; RIMISP: Santiago, Chile, 2016.

36. Cid, B.; Latta, A. Agro-ecology and food sovereignty movements in Chile: Sociospatial practices for alternative peasant futures. Ann. Assoc. Am. Geogr. 2015, 105, 397-406. [CrossRef]

37. Moreira-Muñoz, A.; Leguía, M.; Sabaini, C. Ambientes de montaña en transición: Hacia un Sistema sustentable de alimentación en la Región de Valparaíso, Chile. In Die Welt Verstehen-Eine Geographische Herausforderung. Eine Festschrift der Geographie Innsbruck für Axel Borsdorf; Innsbrucker Studienkreis für Geographie: Innsbruck, Austria, 2016; pp. 235-249. ISBN 978-3-901182-43-3. 
38. Freudenberger, C. Agricultural agenda for the twenty-first century. Pro Rege 1988, 16, 15-21. Available online: http://digitalcollections.dordt.edu/pro_rege/vol16/iss4/3 (accessed on 30 March 2019).

39. Du Plessis, C. Towards a regenerative paradigm for the built environment. Build. Res. Inf. 2012, 40, 7-22. [CrossRef]

40. Holling, C.S.; Gunderson, L.H. Resilience and adaptive cycles. In Panarchy. Understanding Transformations in Human and Natural System; Gunderson, L.H., Holling, C.S., Eds.; Island Press: Washington, DC, USA, 2002; pp. 25-62. ISBN 9781559638579.

41. Dahlberg, K. Regenerative food systems. In Management of Agricultural, Forestry and Fisheries Enterprises. Encyclopedia of Life Support Systems (EOLSS); Hudson, R., Ed.; UNESCO, Eolss Publishers: Oxford, UK, 2006; Volume 2, pp. 172-189. ISBN 978-1-84826-200-3.

42. Dahlberg, K.A. Regenerative food systems: Broadening the scope and agenda of sustainability. In Food for the Future; Allen, P., Ed.; John Wiley and Sons: New York, NY, USA, 1993; pp. 75-102. ISBN 978-0471580829.

43. Dahlberg, K. A transition from agriculture to regenerative food systems. Futures 1994, 26, 170-179. [CrossRef]

44. Hedden, W. How Great Cities are Fed; D.C. Health and Company: New York, NY, USA, 1929.

45. Getz, A. Urban foodsheds. Permac. Act. 1991, 24, 26-27.

46. Stagl, S. Local organic food markets: Potentials and limitations for contributing to sustainable development. Empirica 2002, 29, 145-162. [CrossRef]

47. Kloppenburg, J.; Hendrickson, J.; Stevenson, S.T. Coming into the foodshed. Agric. Hum. Values 1996, 13, 33-42. [CrossRef]

48. Peters, C.; Bills, N.; Lembo, A.; Wilkins, J.; Fick, G. Foodshed analysis and its relevance to sustainability. Renew. Agric. Food Syst. 2009, 24, 72-84. [CrossRef]

49. Pretty, J. Towards sustainable food and farming systems in industrialized countries. IJARGE 2000, 1, 77-94. [CrossRef]

50. Álvarez, L. Alimentación de proximidad. Territorializaciones posibles de una alianza entre los mercados municipales y el territorio agrario periurbano de Madrid. Territ. Form. 2017, 12, 3-23. [CrossRef]

51. Saavedra, A.; Domingos, T.; Raposo, M.; De Melo-Abreu, J.; Palma, J. Mapping the Lisbon potential foodshed in Ribatejo e Oeste: A suitability and yield model for assessing the potential for localized food production. Sustainability 2017, 9, 2003. [CrossRef]

52. Zasada, I.; Schmutz, U.; Wascher, D.; Kneafsey, M.; Corsi, S.; Mazzocchi, C.; Monaco, F.; Boyce, P.; Doernberg, A.; Sali, G.; et al. Food beyond the city-Analysing foodsheds and self-sufficiency for different food system scenarios in European metropolitan regions. City Cult. Soc. 2017, 16, 25-35. [CrossRef]

53. Galzki, J.C.; Mulla, D.J.; Meier, E. Mapping potential foodsheds using regionalized consumer expenditure data for Southeastern Minnesota. J. Agric. Food Syst. Community Dev. 2017, 7, 181-196. [CrossRef]

54. Galzki, J.C.; Mulla, D.J.; Peters, C. Mapping the potential of local food capacity in Southeastern Minnesota. Renew. Agric. Food Syst. 2014, 30, 364-372. [CrossRef]

55. Sali, G.; Corsi, S.; Monaco, F.; Mazzocchi, C.; Glavan, M.; Pintar, M. Urban-rural relationships in feeding metropolis: A case study in Ljubljana metropolitan area. Adv. Eng. Forum 2014, 11, 259-264. [CrossRef]

56. Giombolini, K.; Chambers, K.; Schlegel, S.; Dunne, J. Testing the local reality: Does the Willamette Valley growing region produce enough to meet the needs of the local population? A comparison of agriculture production and recommended dietary requirements. Agric. Hum. Values 2011, 28, 247-262. [CrossRef]

57. Hu, G.; Wang, L.; Arendt, S.; Boeckenstedt, R. An optimization approach to assessing the self-sustainability potential of food demand in the Midwestern United States. J. Agric. Food Syst. Community Dev. 2011, 2, 195-207. [CrossRef]

58. Kremer, P.; DeLiberty, T. Local food practices and growing potential: Mapping the case of Philadelphia. Appl. Geogr. 2011, 31, 1252-1261. [CrossRef]

59. Peters, C.; Bills, N.; Lembo, A.; Wilkins, J.; Fick, G. Mapping potential foodsheds in New York State: A spatial model for evaluating the capacity to localize food production. Renew. Agric. Food Syst. 2008, 24, 72-84. [CrossRef]

60. Swiader, M.; Szevranski, S.; Kazak, J. Foodshed as an example of preliminary research for conducting environmental carrying capacity analysis. Sustainability 2018, 10, 882. [CrossRef]

61. Billen, G.; Barles, S.; Chatzimpiros, P.; Garnier, J. Grain, meat and vegetables to feed Paris: Where did and do they come from? Localising Paris food supply areas from the eighteenth to the twenty-first century. Reg. Environ. Chang. 2012, 12, 325-335. [CrossRef] 
62. Billen, G.; Barles, S.; Garnier, J.; Rouillard, J.; Benoit, P. The food-print of Paris: Long-term reconstruction of the nitrogen flows imported into the city from its rural hinterland. Reg. Environ. Chang. 2009, 9, 13-24. [CrossRef]

63. Rodríguez, B. Nuestro pan de cada día: Huella ecológica alimentaria de Bogotá. In Anais do X Encontro de Geógrafos da América Latina; Universidade de São Paulo: São Paulo, Brazil, 2005.

64. Henríquez, C.; Mallea, C.; Henríquez-Dole, L.; Samaniego, H. Dispersión y escalamiento urbano en el sistema de ciudades chileno urban sprawl and scaling in the Chilean cities system. Investig. Geogr. Chile 2017, 54, 5-22. [CrossRef]

65. Rojas, C.; Sepúlveda-Züñiga, W.; Barbosa, O.; Rojas, O.; Martínez, C. Patrones de urbanización en la biodiversidad de humedales urbanos en Concepción metropolitano. Rev. Geogr. Norte Gd. 2015, 61, 181-204. [CrossRef]

66. ODEPA. Impacto de la Expansión Urbana Sobre el Sector Agrícola en la Región Metropolitana de Santiago; Oficina de Estudios y Políticas Agrarias, Ministerio de Agricultura: Santiago de Chile, Chile, 2012.

67. Bengoa, J. La vía chilena al "sobre" capitalismo agrario. An. Univ. Chile 2017, 12, 73-93. [CrossRef]

68. Servicio Nacional de Aduanas. Registros de Importación y Exportación; Ministerio de Hacienda: Santiago de Chile, Chile, 2016.

69. MINSAL. Marco Conceptual Sobre los Factores Condicionantes de los Ambientes Alimentarios en Chile; Ministerio de Salud, Facultad de Medicina Universidad de Chile: Santiago de Chile, Chile, 2016.

70. Panez-Pinto, A.; Mansilla-Quiñones, P.; Moreira-Muñoz, A. Agua, tierra y fractura sociometabólica del agronegocio. Actividad fruitcola en Petorca, Chile. Bitácora 2018, 28, 153-160. [CrossRef]

71. Sarricolea, P.; Herrera-Ossandon, M.; Meseguer-Ruiz, Ó. Climatic regionalization of continental Chile. J. Maps 2017, 13, 66-73. [CrossRef]

72. Aguayo, M.; Pauchard, A.; Azócar, G.; Parra, O. Cambio del uso del suelo en el centro sur de Chile a fines del siglo XX. Entendiendo la dinámica especial y temporal del paisaje. Rev. Chil. Hist. Nat. 2009, 82, 261-374. [CrossRef]

73. Cid, B. Movimientos agroecológico y neo campesino: Respuestas postmodernas a la clásica cuestión agraria. Agroalimentaria 2014, 20, 65-78.

74. Cid, B. Agroecología y agricultura orgánica en Chile: Entre convencionalización y ciudadanía ambiental. Agroalimentaria 2011, 17, 15-27.

75. Rojas, C.; Muñoz, I.; García-López, M. Estructura urbana y policentrismo en el Área Metropolitana de Concepción. Rev. Eure 2009, 35, 47-70.

76. Aliste, E.; Almendras, A.; Contreras, M. La dinámica del territorio en la conurbación Concepción-Talcahuano: Huellas urbanas para una interpretación de las transformaciones ambientales durante la segunda mitad del siglo XX. Rev. Geogr. Norte Gd. 2012, 52, 5-18. [CrossRef]

77. SERCOTEC. Catastro Nacional de Ferias Libres; Servicio de Cooperación Técnica, Ministerio de Economía, Fomento y Turismo, Gobierno de Chile: Santiago de Chile, Chile, 2016.

78. García Ramón, M.D. Valor actual del modelo de Von Thünen y dos comprobaciones empíricas. Rev. Geogr. 1976, 10, 11-33.

79. Sinclair, R. Von Thünen and urban sprawl. Ann. Assoc. Am. Geogr. 1967, 57, 72-87. [CrossRef]

80. Chisholm, M. Rural Settlement and Land Use; Hutchinson University Library: London, UK, 1962.

81. McMichael, P. A food regime genealogy. J. Peasant Stud. 2009, 36, 139-169. [CrossRef]

82. Gibson-Graham, J.K.; Cameron, J.; Healy, S. Retomemos la Economía. Una Guía Ética Para Transformar Nuestras Comunidades; Editorial Pontificia Universidad Javierana: Bogota, Colombia, 2017; ISBN 9789587810684.

83. Stöhr, W. Selective self-reliance and endogenous regional development-Preconditions and constraints. Iir Discuss. Pap. 1984, 19, 1-21.

84. Sonnino, R. Local foodscape: Place and power in the agri-food system. Acta Agr. Scand. B-S P 2013, 63, 2-7. [CrossRef]

85. Wilhelmina, Q.; Joost, J.; George, E.; Guido, R. Globalization vs. localization: Global food challenges and local solutions. Int. J. Consum. Stud. 2010, 34, 357-366. [CrossRef]

86. Van der Lans, C.J.M.; Hengsdijk, H.; Elings, A.; Van der Schans, J.W.; Aarnink, A.J.A.; Yao, M. Metropolitan Agriculture. Wuhan and Addis Ababa, Two Developing Metropoles; Report GTB-1072; Wageningen UR Greenhouse Horticulture, Ministry of Economic Affairs, Agriculture and Innovation: Wageningen, The Netherlands, 2011. 
87. Sasaki, Y.; Box, P. Agent-based verification of von Thünen's location theory. J. Artif. Soc. Soc. Simul. 2003, 6, $1-9$.

88. Kremer, P.; Schreuder, Y. The feasibility of regional food systems in metropolitan areas: An investigation of Philadelphia's foodshed. J. Agric. Food Syst. Community Dev. 2012, 2, 171-191. [CrossRef]

89. Wiskerke, J.S.C. Rural sociology in the Netherlands: Past, present and future. Agrarwirtsch. Agrarsoziol. 2004, 2, 39-62.

90. Tendall, D.M.; Joerin, J.; Kopainsky, B.; Edwards, P.; Shreck, A.; Le, Q.B.; Kruetli, P.; Grant, M.; Six, J. Food system resilience: Defining the concept. Glob. Food Secur. 2015, 6, 17-23. [CrossRef]

91. Quinlan, A.; Berbés-Blázquez, M.; Haider, J.; Peterson, G. Measuring and assessing resilience: Broadening understanding through multiple disciplinary perspectives. J. Appl. Ecol. 2016, 53, 677-687. [CrossRef]

92. Feenstra, G. Local food systems and sustainable communities. Am. J. Altern. Agric. 1997, 12, 28-36. [CrossRef]

93. Duram, L.; Oberholtzer, L. A geographic approach to place and natural resource use in local food systems. Renew. Agric. Food Syst. 2010, 25, 99-108. [CrossRef]

94. Paredes, M.; Sherwood, S.; Arce, A. La contingencia del cambio social en la agricultura y la alimentación en América Latina. Íconos 2016, 54, 11-25. [CrossRef]

95. Marchant, C.; Fuentes, N. Agricultura Familiar (AF) en América Latina: Desafíos a enfrentar en la era del cambio ambiental global. In Die Welt Verstehen-Eine Geographische Herausforderung. Eine Festschrift der Geographie Innsbruck für Axel Borsdorf; Innsbrucker Studienkreis für Geographie: Innsbruck, Austria, 2016; pp. 221-234. ISBN 978-3-901182-43-3.

(C) 2019 by the authors. Licensee MDPI, Basel, Switzerland. This article is an open access article distributed under the terms and conditions of the Creative Commons Attribution (CC BY) license (http://creativecommons.org/licenses/by/4.0/). 